David Herbert and Stefan Fisher-Høyrem (Eds.)

Social Media and Social Order 

David Herbert and Stefan Fisher-Høyrem (Eds.)

\section{Social Media and Social Order}

Managing Editor: Katarzyna Inga Michalak

Associate Editor: Francesca Corazza

Language Editor: Michael Evans 
ISBN 978-83-66675-60-5

e-ISBN (PDF) 978-83-66675-61-2

e-ISBN (EPUB) 978-3-11-076040-8

\section{(cc) BY-NC-ND}

This work is licensed under the Creative Commons Attribution 4.0 International license (CC BY 4.0)

For details go to http://creativecommons.org/licenses/by/4.0

\section{Library of Congress Cataloging-in-Publication Data}

A CIP catalog record for this book has been applied for at the Library of Congress.

Copyright $\odot 2021$ David Herbert, Stefan Fisher-Høyrem and chapters' contributors

Published by De Gruyter Poland Ltd, Warsaw/Berlin

Part of Walter de Gruyter GmbH, Berlin/Boston

The book is published with open access at www.degruyter.com.

Managing Editor: Katarzyna Inga Michalak

Associate Editor: Francesca Corazza

Language Editor: Michael Evans

Preparation and publication of this book was financially supported by the Research Council of Norway.

The Research Council

of Norway

www.degruyter.com

Cover illustration: geralt/pixabay 